\title{
30 Years of Entrepreneurial Team Research: Review and Suggestions for Developing the Field
}

\author{
Stephanie Schoss ${ }^{1,}$, , Malte Brettel ${ }^{1}$, Rene Mauer ${ }^{2}$ \\ ${ }^{1}$ Institute for Innovation and Entrepreneurship (WIN), RWTH Aachen University, Aachen, Germany \\ ${ }^{2}$ ESCP Europe Wirtschaftshochschule Berlin, Jean-Baptiste Say Institute for Entrepreneurship, Berlin, Germany \\ Email address: \\ Stephanie@schoss.com (S. Schoss), schoss@win.rwth-aachen.de (S. Schoss), brettel@win.rwth-aachen.de (M. Brettel), \\ rmauer@escpeurope.eu (R. Mauer) \\ ${ }^{*}$ Corresponding author
}

\section{To cite this article:}

Stephanie Schoss, Malte Brettel, Rene Mauer. 30 Years of Entrepreneurial Team Research: Review and Suggestions for Developing the Field. Science Journal of Business and Management. Vol. 9, No. 3, 2021, pp. 162-177. doi: 10.11648/j.sjbm.20210903.13

Received: June 7, 2021; Accepted: July 1, 2021; Published: July 13, 2021

\begin{abstract}
This article provides a detailed review of entrepreneurial team (ET) research over 30 years across the fields of entrepreneurship, management, organizational science and psychology. 145 articles from 24 journals were identified, analyzed, and classified in the comprehensive, overarching Upper Echelons Input-Mediator-Outcome framework. This overview contributes by organizing ET research into its sub-domains, analyzing their historic developments and trends, providing guidance for positioning future research, and offering trend-based suggestions how the field can be further developed. Our analysis shows that 30 years ago, ET research was mainly concerned with the formation of ETs, and linking the founding team to venture success. During the last two decades, the focus shifted to deeper analyses of particular mediating variables, such as cognitive and affective emerging states. The most influential articles (by weighted citation) belong to the sub-domain of team composition, which has also become the most frequently studied field during the last 10 years. Authors around the world and from other scientific fields (especially management and organizational science) are now contributing to this domain, which was earlier confined mainly to entrepreneurship scholars from North America. The most widely addressed issues of concern are the lack of theoretical studies and longitudinal data, a bias towards the technology industry, the unavailability of primary data from new ventures, and conflicting findings, especially in the main trending sub-domain of team composition research and in particular on the impact of personality aspects and behavioural dynamics.
\end{abstract}

Keywords: Entrepreneurship, Entrepreneurial Team Research, Input-Mediator-Output Framework, Literature Review, Content Analysis

\section{Introduction}

The significance of teams in the entrepreneurial process was first acknowledged by Cooper and Bruno [20], who found that the majority of successful high technology ventures were started by groups rather than individuals. Subsequently, researchers slowly started to emphasize the importance of teams in the entrepreneurial process $[9,75]$. However, many years later, scholars interested in the human component of entrepreneurship continued to focus on the characteristics of the individual entrepreneur [34]. This focus characterized the early trait studies of entrepreneurship [57]. Likewise, other academic fields in these years, such as the sociological and economic studies of the human component of entrepreneurship, emphasized individuals [e.g. 2, 10]. Some early scholars, such as Gartner et al. (1994), drew attention to the field of team studies in the context of entrepreneurship with their oftencited statement: "the "entrepreneur" in entrepreneurship is more likely to be plural, rather than singular' [39]. In this way, they supported the frequently cited initial study of entrepreneurial team research by Kamm et al. [48], who called for a deeper study of teams, specifically in the entrepreneurial context. However, in the following decade, 
little light was shed on the questions asked, and no systematic research field was established; rather, only some first exploratory steps were taken. Following Kamm et al. [48], a few researchers studied the differential aspects of entrepreneurial teams in the late 1990s [39, 61]. Only more recently has the role of teams re-emerged as a critical component in the study of entrepreneurship [24, 27, 69, 85]. Forbes et al. [34] argue that the shift to a team-based approach constitutes evidence of the theoretical maturation of entrepreneurship research, which increasingly explores new venture creation at multiple levels of analysis. The increasing interest in entrepreneurial teams also reflects prevalent insights from practice. Venture capitalists, for example, consistently mention the quality of new venture teams as an important funding criterion [83].

In the last three decades, numerous researchers have focused on topics such as the relationship between diversity and entrepreneurial teams $[12,18,22,67,69,77,84]$. Research has emphasized how cultural, demographic and various other aspects of diversity affect entrepreneurial teams and, in turn, how they affect business success. Scholars have also looked into several behavioural and cognitive processes that impact entrepreneurial teams [44]. The field of research on entrepreneurial teams (ETs) has matured from establishing their importance to encompassing a diversity of issues relating to the impact that these teams have on various facets of new venture outcomes. The research on ETs represents a constructive and promising development, and important empirical insights about entrepreneurial teams have been accumulated $[19,35,55,68,77]$. However, our understanding of ETs is still limited by theoretical inconsistencies, knowledge gaps, and contradicting predictions; therefore, additional conceptual and theoretical work on the various aspects of venture teams is needed [34, 63, 64].

Taking into account the discussions of previous researchers, this study provides a detailed interpretation of the entrepreneurial team research by identifying, classifying and analysing 145 articles across entrepreneurship, management, organizational science and psychology journals. We then provide not only an organizing framework to track this literature over a 30 -year period but also guidelines for scholars who seek to position their future research efforts and trend-based suggestions on how the field can be further developed. Therefore, we are guided by the following questions:

1. How can we map the territory of ET research in terms of the structure and evolution of its sub-categories over the last three decades to provide a more holistic interpretation and categorization of the field?

2. What have been the most impactful contributors (scholars, journals) to the content development of the field?

3. Building on the research trends of the past 10 years, how can this field of study position itself in the future?

The first question involves a classification of articles to evaluate the disciplinary evolution and to determine the ex post facto priorities of authors, editors, and reviewers. To address the first question, we examine the content of the different subfields and their evolution over time. To tackle the second question, we identify the most prolific authors in the field and the most impactful journals through a systematic literature review. The third question entails a structured overview of the recent research agenda and the current calls for further research in the field. To address the third question, we evaluate the theoretical inconsistencies and knowledge gaps and summarize the recent trends that require further research.

This paper is structured as follows. First, we review and discuss the literature on entrepreneurial teams to reveal predominant theories. Section two then describes the method employed in this study. Section three presents the analysis and results of how the research field has developed over time by considering the articles published on ET research per author and journal. Section four describes how the 145 articles differ in terms of method and design. Section five discusses the current state of the field, and finally, section six summarizes the findings of the paper and provides reasoned conclusions as to the current thinking in the field and possible future developments.

The aimed contribution of this review is to serve as a strategic platform for entrepreneurship and management scholars to understand the legacy of ET research and to direct them towards current and future trends based on quantitative facts and qualitative measures (i.e., most prolific authors and most cited articles and themes covered).

The overall goal is to identify a substantive difference in how scholars might classify, conceptualize and evaluate the research in their respective fields based on the overview of the past 30 years of ET research mapped in an overarching research framework.

\section{Materials and Methods}

A systematic review process in three stages as developed by Tranfield et al. [76] was followed to conduct a structured literature review.

In the identification phase, the need for a review in the field of entrepreneurial teams was derived through a proposal for a review that was discussed and approved in an academic expert group of five entrepreneurship researchers at the RWTH Aachen. Based on the developed objective of the review, a set of research questions was formed, and a review protocol was developed. The conduction phase of the review was structured as follows: the expert group first identified the research coverage area to ensure complete coverage of the ET literature across different scholarly fields. We finally analysed 22 journals from the following four fields: entrepreneurship (Entrepreneurship: Theory and Practice, Journal of Business Venturing, Small Business Economics, Journal of Small Business Management, Journal of Entrepreneurship and Management, International Small Business Journal, Strategic Entrepreneurship Journal); general management (Human Resource Management Review, 
Academy of Management Journal, Academy of Management Review, Journal of Management, Journal of Management Studies, Strategic Management Journal, Management Science, Business Research, International Business Review, Journal of Business Research, Long Range Planning); organizational science (Administrative Science Quarterly, Journal of Organizational Behavior, Organization Science); and psychology (Applied Psychology). The study quality assessment was based on journal ranking and impact factors to ensure that these journals have a high impact in their respective fields $[13,37,65]$.

As the starting point for the review period, we propose the year 1990, when Kamm et al. [48] identified ET as a new research field in their seminal study. By using the 'Business Source Complete' database, 145 articles were searched and later analysed. All articles satisfied the following criteria: first, they were published in one of the journals mentioned; second, they were published between 1990 and 2019; and third, they contain the keywords 'team' or 'group' (or both) and (cumulatively) one or more of the keywords 'entrepreneur', 'entrepreneurial', 'entrepreneurship', 'start up' (or 'startup' or 'start-up') and 'new venture' in the title or in the abstract $[1,13]$. Book reviews, editor's notes, and replies to the already published articles were omitted. Although this approach does not cover non-journal publications, we are confident that it provides an accurate and representative picture of the areas on which ET scholars have chosen to focus their research attention. To represent the full range of research, both conceptual and empirical articles were included [65].

To avoid the arbitrariness implied by subjectively generated keywords for search engines, three coders manually went through all issues of all journals to first select the relevant articles and later code them according to the framework described below. Taking into consideration practical constraints, the data set was not intended to be complete and exhaustive but rather a representation of the field. To analyse how the research has evolved over time, the 30-year period was divided into five 6-year periods, namely, 1990-1995 (P1), 1996-2001 (P2), 2002-2007 (P3), 20082013 (P4), and 2014-2019 (P5). Our analysis of the structure and evolution of the field is based on quantitative data rather than qualitative interpretation.

The methodology of the present review is enriched by the elements of a content analysis, which is an approach often used for literature reviews [1, 38, 49]. This approach is an important means for the objective, systematic and quantitative consideration of published research that helps interpret the direction in which the field of study has evolved and can evolve over time [38]. To perform the review, an organizing framework is needed. This framework can either be deductively based on existing theory or literature or it can be inductively grounded in data [26]. Inductively grounding in data can result in a more unbiased and impartial view, as no theoretical assumptions are taken for granted [56]. However, such an inductive approach also limits the comparability and compatibility with existing research, and this issue has been criticized by various authors as one of the key challenges of entrepreneurial team research [50]. To resolve this problem, the input-mediatoroutcome (IMO) model - as a key overarching theory framework in the greater field of team research - is used as a code-based analytical framework. The IMO model is a modification and extension of the input-process-output (IPO) model, which was originally advanced by McGrath [59]. Inputs include individual team member characteristics, team-level factors and contextual factors, and outputs contain firm performance or members' affective reactions; both inputs and outputs are linked via processes and emergent states (dynamic team characteristics including cognitive, motivational, and affective states) [54, 56]. The resulting organizing framework is mainly based on the work of Mathieu et al. [56] and Klotz et al. [50] who have theoretically and qualitatively shaped the IMO model in the field of (entrepreneurial) teams.

This procedure yielded a final list of 145 articles, which are summarized in Appendix 1. To analyse these articles, an organizing framework derived from this list of articles is necessary to systematically evaluate their contributions [40]. We derived this framework as follows. To ensure objectivity, each coder read each of the 145 articles and independently analysed the article's definition of ETs, research focus, theoretical framework, variables, data and method, outcomes, and theoretical implications for ET research. The individual coders' assessments were later combined and synthesized. Disagreements among coders regarding this analysis were discussed in the group and resolved. By clustering all articles according to their main research focus, the IMO model has been adapted slightly to better fit the data at hand (through several iterations of open coding). According to these categories, all research papers were classified and sub-classified (Table 1). The classification according to the categories and subcategories was straightforward in cases where the article explicitly studied a particular research theme. However, the articles that focused on more than one research stream were classified on the basis of their main focus of attention. To ensure that each article was classified correctly, a two-step approach was applied. First, each coder evaluated the articles independently for a main focus theme. In the second step, the allocations of articles across subfields were compared, and disagreements were discussed and solved through discussion [38]. This process yielded a coding matrix (Table 1) for all articles that provided information for the subsequent analysis, whose results are discussed in the following section.

By assigning each article to one research focus dimension, mainly independent or moderating variables are considered. This is also the case for our research, as none of the articles' main focus was based on entrepreneurial team outcomes such as team performance, which leads to the exclusion of this final aspect of the IMO model. This exclusion occurs because the outcome variables are mainly seen as dependent variables that are influenced by either input or mediating variables. 
Table 1. IMO dimensions and their role in ET research.

\begin{tabular}{|c|c|c|c|c|c|c|c|c|c|c|c|c|c|}
\hline & \multirow{2}{*}{ Scoring Dimensions } & \multicolumn{2}{|l|}{ P1 } & \multicolumn{2}{|l|}{$\mathbf{P 2}$} & \multicolumn{2}{|l|}{ P3 } & \multicolumn{2}{|l|}{$\mathbf{P 4}$} & \multicolumn{2}{|l|}{ P5 } & \multicolumn{2}{|c|}{ Total } \\
\hline & & No. & $\%$ & No. & $\%$ & No. & $\%$ & No. & $\%$ & No. & $\%$ & No. & $\%$ \\
\hline & Total & 8 & 100 & 8 & 100 & 30 & 100 & 54 & 100 & 45 & 100 & 145 & 100 \\
\hline & Input & 2 & 25 & 3 & 38 & 13 & 43 & 25 & 46 & 27 & 60 & 70 & 48 \\
\hline & Team context & 0 & 0 & 0 & 0 & 2 & 7 & 5 & 9 & 5 & 11 & 12 & 8 \\
\hline & Team composition & 1 & 13 & 3 & 38 & 11 & 37 & 19 & 35 & 22 & 49 & 56 & 39 \\
\hline & Surface level traits / diversity & 1 & 13 & 0 & 0 & 10 & 33 & 16 & 30 & 17 & 38 & 44 & 30 \\
\hline & Demographic & 0 & 0 & 0 & 0 & 4 & 13 & 2 & 4 & 2 & 4 & 8 & 6 \\
\hline & Gender & 0 & 0 & 0 & 0 & 0 & 0 & 1 & 2 & 1 & 2 & 2 & 1 \\
\hline & Knowledge / Education & 1 & 13 & 0 & 0 & 3 & 10 & 6 & 11 & 4 & 9 & 14 & 10 \\
\hline & Family ties & 0 & 0 & 0 & 0 & 0 & 0 & 1 & 2 & 2 & 4 & 3 & 2 \\
\hline & Ownership / equity & 0 & 0 & 0 & 0 & 0 & 0 & 0 & 0 & 1 & 2 & 1 & 1 \\
\hline & Mix / other & 0 & 0 & 0 & 0 & 3 & 10 & 5 & 9 & 5 & 11 & 13 & 9 \\
\hline & Deep-level traits / diversity & 0 & 0 & 2 & 25 & 1 & 3 & 3 & 6 & 4 & 9 & 10 & 7 \\
\hline & Mix / other & 0 & 0 & 1 & 13 & 0 & 0 & 0 & 0 & 1 & 2 & 2 & 1 \\
\hline \multirow[t]{16}{*}{ Categories } & Mediator & 2 & 25 & 3 & 38 & 9 & 30 & 19 & 35 & 9 & 20 & 42 & 29 \\
\hline & Processes & 1 & 13 & 1 & 13 & 4 & 13 & 6 & 11 & 3 & 7 & 15 & 10 \\
\hline & Action & 0 & 0 & 0 & 0 & 1 & 3 & 1 & 2 & 0 & 0 & 2 & 1 \\
\hline & Interpersonal & 1 & 13 & 1 & 13 & 3 & 10 & 5 & 9 & 3 & 7 & 13 & 9 \\
\hline & Emergent states & 1 & 13 & 2 & 2 & 3 & 10 & 10 & 19 & 3 & 7 & 19 & 13 \\
\hline & Cognitive & 1 & 13 & 1 & 13 & 2 & 7 & 3 & 6 & 0 & 0 & 7 & 5 \\
\hline & Motivational & 0 & 0 & 0 & 0 & 0 & 0 & 1 & 2 & 0 & 0 & 1 & 1 \\
\hline & Affective & 0 & 0 & 1 & 1 & 1 & 3 & 6 & 11 & 3 & 7 & 11 & 8 \\
\hline & Blended mediators & 0 & 0 & 0 & 0 & 2 & 7 & 3 & 6 & 3 & 7 & 8 & 6 \\
\hline & Team learning & 0 & 0 & 0 & 0 & 0 & 0 & 1 & 2 & 2 & 4 & 3 & 2 \\
\hline & Behavioural integration & 0 & 0 & 0 & 0 & 2 & 7 & 0 & 0 & 1 & 2 & 3 & 2 \\
\hline & Transactive memory systems & 0 & 0 & 0 & 0 & 0 & 0 & 2 & 4 & 0 & 0 & 2 & 1 \\
\hline & Evolution & 4 & 50 & 2 & 25 & 8 & 27 & 9 & 17 & 6 & 13 & 29 & 20 \\
\hline & Formation & 3 & 38 & 0 & 0 & 3 & 10 & 5 & 9 & 2 & 4 & 13 & 9 \\
\hline & Transformation & 1 & 13 & 2 & 25 & 5 & 17 & 4 & 7 & 4 & 9 & 16 & 11 \\
\hline & Mix / Literature Review & 0 & 0 & 0 & 0 & 0 & 0 & 1 & 2 & 3 & 7 & 4 & 3 \\
\hline
\end{tabular}

\section{Results}

\subsection{Theoretical Developments}

To understand the future of entrepreneurial team research, it is important to provide a historical perspective on the origins of the observed changes and evolutions in the development of the explicit and implicit theoretical groundwork in this field. Implicit theories reflect beliefs about cause-and-effect relationships, underpin the explication of phenomena, and help define conceptual categories that represent a starting point from which we can develop higherlevel concepts, properties, and relationships.

When analysing the 145 articles for a profound theory base, we followed the recommendations of Weick [80] on what theory is and what it is not. He especially emphasizes the difficulty of what passes in new fields of research (such as ET research) for theory often consists only of approximations that rarely take the form of a strong theory. This may result from interim struggles of profound theorizing processes or may actually be the results from lazy and incompetent theorizing. He endorses that theory is neither something that one 'adds' nor something one transforms from weaker into stronger through graphics, references or a flashy conceptual performance. Based on Weick's [80] definition of what good theory actually is, we found very few articles for theory development or conceptual approaches over the last 30 years that seek to develop unique theoretical knowledge and coherence, such as Harper's important theory of entrepreneurial teams [41]. The following paragraphs provide a brief overview of the theoretical and conceptional development of the ET research over the past three decades.

At the beginning of ET research, Kamm et al. [48] first set a new research agenda for entrepreneurial teams and called for more empirical research on the pre-start-up phase of new ventures, a better understanding of the configuration and compensation options for teams and the conditions under which these options are most effective. Their review became a seminal paper that has been cited 511 times since its publication (18 times per year).

Three years later, Kamm and Nurick [47] aimed to create a new model for the stages of team venture formation. Their attempt seemed to be appropriate because the formation of teams was an early topic of interest in the field. In 1998, Mosakowski [61] published a broader model of entrepreneurship that emphasized the locus of entrepreneurial resources, which are defined as the behavioural propensities of individuals to be creative, intuitive, alert, and farsighted. This model was referenced by many scholars as an example to follow. Over the last two decades, there has been an evolution of the models that use cause-and-effect relationships to explain particular phenomena, such as Francis and Sandberg's [35] 
model of the effect of friendship on entrepreneurial teams or the intentions-based model of entrepreneurial teams' social cognition [70]. Ensley et al. [28] use a behavioural integration perspective in articulating the process through which new venture performance can be explained. They integrate concepts from entrepreneurship, top management team research, group processes and leadership research to propose a new inputprocess-output model. They describe their model as a springboard for future research that encourages crossdisciplinary approaches and refocuses attention on entrepreneurial behaviour in the creation of new venture performance. However, after several years, we find that their call has yet to be adequately addressed.

Our analysis reveals that over $30 \%$ of the articles on entrepreneurial team research do not even use a clearly stated theoretical framework to tackle their research question. The upper echelon framework is most frequently used as an auxiliary model. The remaining studies have used theoretical frameworks and foundations that belong mainly to the fields of entrepreneurship, psychology, and management to explain their findings $[61,51,23]$. From these disciplines, the theories most frequently used are human capital theory, the resource dependence perspective, social capital theory, identity theory and agency theory $[72,78]$.

A particularly dissatisfying result of the analysis is that only a few of the 145 articles seek to develop unique knowledge and a coherent view of the field like Harper [41] accomplished. This triggers a vicious circle because the lack of strong theoretical foundations implies that it is difficult to develop stable hypotheses, which reinforces the tendency for phenomenon-driven rather than theory-driven work [49].

\subsection{Research Streams}

Over recent decades, the ET research has explored numerous fields. Table 1 classifies the selected papers according to their research streams. Over the last three decades, most articles have focused on input variables (48\%), mediating variables (29\%) and team evolution (20\%). Team evolution was strong in P1 (1990-1995) with 50\%, whereas team composition and mediating variables were predominant in the succeeding period P2 (1996-2001) with 38\% each. The relative share of published papers clearly shifted towards the topic of team composition during the next three periods of $\mathrm{P} 3$ (2002-2007), P4 (2008-2013), and P5 (2014-2019), which were also marked by a relative decline in the share of articles on mediating and team evolution variables. We interpret this as a trend in favour of one particular input variable: team composition. This trend can also be confirmed by our citation index of the most impactful papers (see 3.3).

Team evolution was a popular focus in the entrepreneurial team research among the scholars of the first period, but its popularity clearly declined over the course of succeeding periods (from $50 \%$ in $\mathrm{P} 1$ to $13 \%$ in P5). There has also been an early emphasis on the study of team formation (38\% of all team evolution studies in P1) [19, 48, 58].

The input variables - particularly team composition as a field of study - have come into focus and account for $60 \%$ of the articles in the last six years (P5). The overall majority of the literature in this sub-field belongs to surface-level diversity studies (38\% in P5 and 30\% overall since 1990), whereas deep-level diversity analysis has been relatively neglected ( $7 \%$ overall). Surface-level diversity refers to easily detectable characteristics, e.g., not only the demographic data of an individual but also his or her functional or educational backgrounds [60]. In contrast, deep-level diversity refers to the characteristics of an individual that are unique to him or her, such as personality, attitude, and beliefs [42]. Most articles that cover surfacelevel variables either focus on the effects of an individual's knowledge or educational background $(10 \%)$ or are a mix of different variables (9\%); consider, e.g., Foo [30] who created various indices for race and non-task diversity. This finding supports Klotz et al. [50] who concluded that within the field of new venture team research, 'prior experience' has received considerable research attention. We notice that after a strong second period (P2), deep-level diversity lost academic attention in periods $\mathrm{P} 3$ and $\mathrm{P} 4$ (from $25 \%$ to $3 \%$ and $6 \%$, respectively) but has seen an increase in P5 to $9 \%$. Current authors who publish about deep-level diversity rank high in our statistics for important authors and articles (see 3.3), which provides reason to assume that this particular field may be a latent trend in the entrepreneurial literature (which is not easy to detect by absolute numbers). Additionally, in their meta-analytical review, Zhao et al. [84] conclude that the personality traits of an individual play an imperative role in the emergence and success of entrepreneurs, and, accordingly, they summarize the calls of other researchers for a greater focus on deep-level diversity at the team composition level [66, 79].

Another upcoming area of focus in the ET research over the years is the field of mediating variables. Both team processes and emergent states have received similar amounts of research attention, at $10 \%$ and $13 \%$, respectively. Nevertheless, particularly in P1, the articles that used a mediator as an explanatory variable largely focused on interpersonal processes. These interpersonal processes 'describe activities that involve the management of interpersonal relationships (e.g., conflict management, motivating and confidence building, and affect management)' [50]. In addition, the cognitive and affective emergent states received an upsurge of interest in P2, and they were as widely researched as interpersonal team processes. The cognitive constructs mainly focus on the thinking and decision-making processes, and the affective constructs focus on experienced feelings and moods [50]. Influential papers in the cognitive emerging-state field are from Li et al. [52], who analyse the moderating effect of entrepreneurial orientation on a firm's performance, and from West [81], who evaluates the importance of collective cognition. Foo et al. [32] contribute to the affective emerging state research by analysing the effect of feelings on effort, with Maw-Der Foo being one of the most active authors in the field of entrepreneurial research in general (see 3.3). In contrast to the increasing emphasis on input variables, the research on 
moderating variables seems to leave some room for improvement despite the expectation that this stream will grow, as noted by various researchers [21].

\subsection{Journals and Authorship}

Table 2 shows that the major developments in the field of entrepreneurial team research have occurred over the last decade, during which the amount of research on entrepreneurial teams increased markedly: from 8 studies in P1 to 54 studies in P4 and ending with a decrease to 45 studies in $\mathrm{P} 5$. In fact, in P4, almost three times as many articles were published in the listed journals than in P1 and P2 combined.

Table 2. List of journals.

\begin{tabular}{|c|c|c|c|c|c|c|c|c|c|c|c|c|c|}
\hline \multirow{2}{*}{ List of Journals } & \multirow{2}{*}{$\begin{array}{l}\text { Rating (VHB) / } \\
\text { Impact Factor }\end{array}$} & \multicolumn{2}{|l|}{ P1 } & \multicolumn{2}{|l|}{$\mathbf{P 2}$} & \multicolumn{2}{|l|}{ P3 } & \multicolumn{2}{|l|}{$\mathbf{P 4}$} & \multicolumn{2}{|l|}{ P5 } & \multicolumn{2}{|c|}{ Total } \\
\hline & & No. & $\%$ & No. & $\%$ & $\%$ & $\%$ & No. & $\%$ & No. & $\%$ & No. & $\%$ \\
\hline Entrepreneurship & & 7 & 88 & 7 & 88 & 22 & 73 & 40 & 74 & 21 & 47 & 97 & 67 \\
\hline Entrepreneurship Theory and Practice & A / 6.19 & 3 & 38 & 1 & 13 & 11 & 37 & 15 & 28 & 5 & 11 & 35 & 24 \\
\hline International Small Business Journal & $\mathrm{C} / 3.71$ & 0 & 0 & 0 & 0 & 1 & 3 & 0 & 0 & 0 & 0 & 1 & 1 \\
\hline Journal of Business Venturing & $\mathrm{A} / 5.33$ & 2 & 25 & 2 & 25 & 9 & 30 & 8 & 15 & 6 & 13 & 27 & 19 \\
\hline Journal of Entrepreneurship and Management & $\mathrm{n} / \mathrm{a} / 2.53$ & 0 & 0 & 0 & 0 & 0 & 0 & 0 & 0 & 1 & 2 & 1 & 1 \\
\hline Journal of Small Business Management & $\mathrm{B} / 3.12$ & 2 & 25 & 3 & 38 & 1 & 3 & 7 & 13 & 2 & 4 & 15 & 10 \\
\hline Small Business Economics & $\mathrm{C} / 3.55$ & 0 & 0 & 1 & 13 & 0 & 0 & 6 & 11 & 6 & 13 & 13 & 9 \\
\hline Strategic Entrepreneurship Journal & $\mathrm{B} / 2.96$ & 0 & 0 & 0 & 0 & 0 & 0 & 4 & 7 & 1 & 2 & 5 & 3 \\
\hline General Management & & 0 & 0 & 0 & 0 & 7 & 23 & 12 & 22 & 15 & 33 & 34 & 23 \\
\hline Academy of Management Journal & $\mathrm{A}+/ 7.19$ & 0 & 0 & 0 & 0 & 4 & 13 & 3 & 6 & 3 & 7 & 10 & 7 \\
\hline Academy of Management Review & $\mathrm{A}+/ 10.6$ & 0 & 0 & 0 & 0 & 0 & 0 & 2 & 4 & 1 & 2 & 3 & 2 \\
\hline Business Research & $\mathrm{B} / 4.01$ & 0 & 0 & 0 & 0 & 0 & 0 & 1 & 2 & 0 & 0 & 1 & 1 \\
\hline Human Resource Management Review & $\mathrm{C} / 3.62$ & 0 & 0 & 0 & 0 & 2 & 7 & 0 & 0 & 0 & 0 & 2 & 1 \\
\hline International Business Review & $\mathrm{B} / 3.64$ & 0 & 0 & 0 & 0 & 0 & 0 & 0 & 0 & 1 & 2 & 1 & 1 \\
\hline Journal of Business Research & $\mathrm{B} / 4.03$ & 0 & 0 & 0 & 0 & 0 & 0 & 1 & 2 & 1 & 2 & 2 & 1 \\
\hline Journal of Management & $\mathrm{B} / 9.06$ & 0 & 0 & 0 & 0 & 0 & 0 & 3 & 6 & 2 & 4 & 5 & 3 \\
\hline Journal of Management Studies & $\mathrm{B} / 5.84$ & 0 & 0 & 0 & 0 & 0 & 0 & 0 & 0 & 1 & 2 & 1 & 1 \\
\hline Long Range Planning & $\mathrm{B} / 3.36$ & 0 & 0 & 0 & 0 & 0 & 0 & 0 & 0 & 2 & 4 & 2 & 1 \\
\hline Management Science & $\mathrm{A}+/ 4.22$ & 0 & 0 & 0 & 0 & 0 & 0 & 1 & 2 & 1 & 2 & 2 & 1 \\
\hline Strategic Management Journal & $\mathrm{A} / 5.57$ & 0 & 0 & 0 & 0 & 1 & 3 & 1 & 2 & 3 & 7 & 5 & 3 \\
\hline Organizational Science & & 1 & 13 & 1 & 13 & 1 & 3 & 1 & 2 & 5 & 11 & 9 & 6 \\
\hline Administrative Science Quarterly & $\mathrm{A}+/ 8.02$ & 1 & 13 & 0 & 0 & 0 & 0 & 0 & 0 & 0 & 0 & 1 & 1 \\
\hline Journal of Economic Behavior \& Organization & $\mathrm{A} / 1.40$ & 0 & 0 & 0 & 0 & 0 & 0 & 0 & 0 & 1 & 2 & 1 & 1 \\
\hline Journal of Organizational Behaviour & $\mathrm{B} / 5.0$ & 0 & 0 & 0 & 0 & 0 & 0 & 0 & 0 & 1 & 2 & 1 & 1 \\
\hline Organization Science & $\mathrm{A} / 3.26$ & 0 & 0 & 1 & 13 & 1 & 3 & 1 & 2 & 3 & 7 & 6 & 4 \\
\hline Psychology & & 0 & 0 & 0 & 0 & 0 & 0 & 1 & 2 & 2 & 4 & 3 & 2 \\
\hline Journal of Applied Psychology & $\mathrm{A} / 5.06$ & 0 & 0 & 0 & 0 & 0 & 0 & 1 & 2 & 2 & 4 & 3 & 2 \\
\hline
\end{tabular}

The number of articles published on entrepreneurial teams in organizational science and psychology journals was low and stable over the first three periods (P1-P3), but the number of articles published in general management saw a steep increase in P3 and doubled from P3 to P5. Although still small in absolute numbers, a trend of ET research in the field of management can be identified, which is surprising because the related field of top management teams is a wellstudied field of its own in this discipline. This finding suggests that entrepreneurial team research is gaining increasingly more academic legitimacy outside of entrepreneurial journals. Not surprising, however, is the strong increase in the absolute and relative numbers of papers in the entrepreneurship domain, which represents $67 \%$ of publications over the course of the years considered. Overall, $24 \%$ of the ET studies in recent decades were published in Entrepreneurship Theory and Practice (35 studies) followed by the Journal of Business Venturing (27 studies).

\subsection{Contributing Authors}

Bergh et al. [7] stated that key individuals impact both the development of a field of study and the themes that are predominant at a particular period of time. Thus, it is insightful to identify the authors who have been the most published and cited in the field of entrepreneurial team research to understand the past evolution and likely future direction of this field [38].

Entrepreneurial team research is a recent field of study, and the number of publications per author is still relatively small. Only 46 of the authors have published more than one paper in the journals under consideration. Table 3 lists the names of the authors who have published more than one article in the ET research field and can thus be classified as key individuals according to Bergh et al. [7].

The most prolific authors were Clarysse, Foo, Wright, Beckmann, Busenitz, Cardon, Ensley and Hmieleski. Clarysse, Foo and Wright each contributed five papers, and the others contributed four papers each. The topics covered by the three main authors are as follows.

Clarysse, from the ETH Zurich, focuses mainly on team formation (four out of five articles) and partly on heterogeneity factors with a particular interest in the field of academic spin-offs. In 2019, he co-authored 2 articles in the 
journals under consideration; one of these was on deep-level diversity, i.e., different types of team entrepreneurial passion, which they found to benefit ventures only if the type of passion matches the specific development stage that the venture operates in [11].

Foo, from the National University of Singapore, mainly focuses on surface-level diversity research, and he published three out of five of the considered papers in this field. In his 2011 article [30], he examines 'how member characteristics and conflict affect member-rated team effectiveness'. He finds task conflict to be negatively related to member-rated team effectiveness (which contrasts with most past research on this issue).

Table 3. Contributing authors and their number of appearances.

\begin{tabular}{|c|c|}
\hline Author & Appearance No. \\
\hline Clarysse, Bart & 5 \\
\hline Foo, Maw Der & 5 \\
\hline Wright, Mike & 5 \\
\hline Beckman, Christine & 4 \\
\hline Busenitz, Lowell W. & 4 \\
\hline Cardon, Melissa S. & 4 \\
\hline Ensley, Michael & 4 \\
\hline Hmieleski, Keith M. & 4 \\
\hline Burton, Diane & 3 \\
\hline Pearson, Allison W. & 3 \\
\hline Shepherd, Dean A. & 3 \\
\hline Ucbasaran, Deniz & 3 \\
\hline Barnett, Tim & 2 \\
\hline Baron, Robert & 2 \\
\hline Bradley, Steven W. & 2 \\
\hline Breugst, Nicola & 2 \\
\hline Brinckmann, Jan & 2 \\
\hline Eddleston, Kimberly & 2 \\
\hline Franke, Nikolaus & 2 \\
\hline Gruber, Marc & 2 \\
\hline Harhoff, Dietmar & 2 \\
\hline Henkel, Joachim & 2 \\
\hline Hoogendoorn, Sander & 2 \\
\hline Kellermanns, Franz & 2 \\
\hline Klotz, Anthony C. & 2 \\
\hline Knockaert, Mirjam & 2 \\
\hline Lockett, Andy & 2 \\
\hline Moesel, Douglas & 2 \\
\hline Moray, Nathalie & 2 \\
\hline Mosakowski, Elaine & 2 \\
\hline Nurick, Aaron & 2 \\
\hline Parker, Simon C. & 2 \\
\hline Patzelt, Holger & 2 \\
\hline Song, Michael & 2 \\
\hline van Praag, Mirjam & 2 \\
\hline Vissa, Balagopal & 2 \\
\hline Westhead, Paul & 2 \\
\hline Zheng, Yanfeng & 2 \\
\hline zu Knyphausen-Aufse $\beta$, Dodo & 2 \\
\hline Elfring, Tom & 2 \\
\hline Andries, Petra & 2 \\
\hline Agarwal, Rajshree & 2 \\
\hline Kollmann, Tobias & 2 \\
\hline Stöckmann, Christoph & 2 \\
\hline Boeker, Warren & 2 \\
\hline Hoegl, Martin & 2 \\
\hline
\end{tabular}

In contrast, Wright, from Imperial College London, published a well-received and highly requested literature review on the role of human capital in technological entrepreneurship and encouraged additional research on the appropriate timing of the introduction of surrogate entrepreneurs to a founding team [82]. Further studies co-authored by Wright similarly focused on the aspects of team evolution, such as member entry and exit strategies and dynamics.

Additionally, Beckman and Hmieleski focus their research on team composition; Beckman's two articles explore surface-level diversity [4, 6], while Hmielski's paper explores deep-level diversity [44]. This finding only underlines the current importance placed on team composition as an influencing variable. Furthermore, Hmielski co-authored one of the most cited papers (i.e. Klotz et al. [50]) that researches the field of new venture teams from a qualitative perspective together with authors such as Klotz and Busenitz. Busenitz is a more versatile author who has conducted research on input, moderating and team evolution variables $[14,53]$.

To emphasize another insightful paper, in their 2005 publication, Ensley and Pearson [29] progressed from seeking to identifying global characteristics that differentiate successful from less successful entrepreneurs to an in-depth examination of more distinct research questions such as the effect of family ties on behavioural team dynamics, namely, cohesion, conflict, and group potency [29]. In 2003, Ensley et al. [28] developed a new input-process-output model that integrated concepts from the entrepreneurship, top management teams, group process, and leadership research to examine new venture top management teams and new venture performance [28].

Interestingly, both Ensley and Hmieleski published within the least covered research sub-streams of 'deep-level diversity' in entrepreneurial teams. According to the accelerator effect of influential articles [8], we may expect even more publications on traits, attitudes, values, and behavioural influence in the near future.

Regarding the outlets where the top eight authors have published, we note that of the total 35 articles, 13 articles were published in Entrepreneurship Theory and Practice, seven in Journal of Business Venturing, three in Academy of Management Journal, three in Journal of Management, two in Journal of Small Business Management and Academy of Management Review and one each in Strategic Management Journal, Journal of Applied Psychology, Small Business Economics, Organization Science, and Human Resource Management Review, which notably represents the distribution of the ET research across the disciplines of entrepreneurship. This distribution also demonstrates that this particular research field is interdisciplinary and cannot be studied in only one domain. Congruent with the result that the ET research has established itself as a field of research in the last 15 years, the most established authors have also published within recent years. However, this finding is not obvious because we would expect authors from the early 1990s to have produced more pieces of research over the 30year period than younger scholars who enter the field 10 years later. 
In terms of the origin of the authors, we can see that the ET research has slowly become more important outside the US. In the recent decade, papers from North American-based authors constituted, on average, $48 \%$ of all ET research, whereas approximately $27 \%$ of the research is based in Europe, and approximately $6 \%$ is based in Asian countries. In the first two periods, most ET research in the respective journals was produced in the North American region. For an overview of the regional distribution of the origins of ET research, refer to Table 4.

Table 4. Research areas and their presence in ET research over three decades.

\begin{tabular}{lll}
\hline Entrepreneurial team & No. & $\mathbf{\%}$ \\
\hline Yes & 81 & 56 \\
No & 30 & 21 \\
Other / not applicable & 34 & 23 \\
Country / Region & No. & $\%$ \\
North America & 69 & 48 \\
USA & 68 & 47 \\
Canada & 1 & 1 \\
Europe & 39 & 27 \\
Belgium & 5 & 3 \\
Denmark & 1 & 1 \\
France & 2 & 1 \\
Germany & 9 & 6 \\
Great Britain & 6 & 4 \\
Italy & 2 & 1 \\
Luxemburg & 1 & 1 \\
Netherlands & 4 & 3 \\
Norway & 1 & 1 \\
Portugal & 1 & 1 \\
Spain & 2 & 1 \\
Sweden & 1 & 1 \\
Switzerland & 1 & 1 \\
Asia & 9 & 6 \\
China & 4 & 3 \\
Cambodia & 1 & 1 \\
India & 1 & 1 \\
Singapore & 2 & 1 \\
Taiwan & 1 & 1 \\
Other & 6 & 1 \\
Australia & 1 & 1 \\
Georgia & 1 & 1 \\
Honduras & 1 & 1 \\
Israel & 1 & 39 \\
Kenya & 1 & 1 \\
Tunisia & 22 & 1 \\
Unknown & No. & 1 \\
Industry & 41 & 1 \\
Tech & 3 & 1 \\
Services & Other / unknown & 1 \\
\hline & & 1 \\
\hline
\end{tabular}

\subsection{Most Influential Papers}

In every field of science, some publications have assumed seminal roles in the development and advancement of the field of study. Because of their impact, these articles accelerate the development of the field [8]. Thus, it is essential to identify the most significant articles in the ET literature during the period of 1990-2019 to obtain a better understanding of the likely direction of future developments [38]. To measure the impact of a research article, we used the generally accepted method of summed citation counts $[7,73]$.
We identified the most influential articles in the entrepreneurial team research by looking at the number of citations for a particular research paper on Google Scholar. Papers published in earlier periods have a greater chance of having a larger number of citations than papers published in recent years. To overcome this problem and obtain more accurate results, we followed the advice of Furrer et al. [38] and divided the number of citations by the number of years since the paper was published. Table 5 presents the most influential papers in the ET literature within the last 30 years.

Among the 30 most influential papers identified, 16 (53\%) articles study input dimensions; 11 of these primarily focus on team composition, and 5 analyse either the team context or a mix of different aspects. Of the remaining 14 articles, 6 (20\%) concern mediators, and all but one focuses on emerging states; 7 explore team evolution, with almost equally as many concerned with formation (4) as transformation (3), and the last article is a general literature review. This result is not unexpected because over the last few years, team composition has become one of the largest sub-streams in terms of the absolute number of papers published. These 11 most influential papers account for approximately $20 \%$ of all papers published in the subdomain of ET composition. Our organizing framework (Table 1) allows us to analyse the sub-stream of team composition one level deeper: the influential ranking of papers suggests an increasing interest in the deep-level diversity factors, in particular personality characteristics. Although the absolute number of papers that cover personality aspects is rather low (10 out of 145), the influence of these papers is quite high. We find that out of the ten articles published over the last 30 years on personality aspects, two rank among the five most cited papers, and one is within the top ten. To contextualize this finding, two out of the three papers, namely, Zhao et al. [84] and Cardon et al. [15], were a meta-analysis and a literature review, respectively, wherein the format of the study explains part of its popularity. Nevertheless, the point remains that the personality aspect of ETs seems to be a topic of increasing interest with many open questions to solve. This impression is supported by the fact that 2 new articles have been published very recently (in 2019).

In contrast, for the additionally well-studied subfield of moderators, only a very limited number of the many published papers appear in the ranking of most influential articles. This result is surprising; however, it supports our assumption that team composition and especially deep-level diversity may indicate a trend in the research, and there is reason to predict that the number of articles that analyse the personality aspects of team composition will increase in the coming years. This assumption was first raised in the metaanalysis of Zhao et al. [84] on the relationship of personality with venture performance, where they suggest that personality plays a vital role in the emergence and success of entrepreneurs. Nevertheless, the relatively small number of highly influential studies on emergent states may be all the more reason to discuss this topic and to identify the ways in which it can be further developed in the future. Coultas et al. 
[21], for example, conducted an extensive review of emergent state measurement, which included the identification of common measurement problems and possible solutions (for work teams in general, not specifically for the entrepreneurial team context) on which further research could be based.

Table 5. Most influential articles by number of citations.

\begin{tabular}{|c|c|c|c|c|c|}
\hline Journal & Authors & Year & Title & $\begin{array}{l}\text { Cited } \\
\text { by }\end{array}$ & $\begin{array}{l}\text { Weighted } \\
\text { citations }\end{array}$ \\
\hline Journal of Management & $\begin{array}{l}\text { Zhao, Seibert \& } \\
\text { Lumpkin }\end{array}$ & 2010 & $\begin{array}{l}\text { The relationship of personality to entrepreneurial intentions and } \\
\text { performance: A meta analytic review }\end{array}$ & 791 & 99 \\
\hline $\begin{array}{l}\text { Academy of } \\
\text { Management Review }\end{array}$ & $\begin{array}{l}\text { Cardon, Wincent, Singh } \\
\text { \& Drnovsek }\end{array}$ & 2009 & The nature and experience of entrepreneurial passion & 858 & 95 \\
\hline $\begin{array}{l}\text { Administrative Science } \\
\text { Quarterly }\end{array}$ & $\begin{array}{l}\text { Eisenhardt \& } \\
\text { Schoonhoven }\end{array}$ & 1990 & $\begin{array}{l}\text { Organizational Growth: Linking Founding Team, Strategy, Environment, } \\
\text { and Growth Among U.S. Semiconductor Ventures, 1978-1988 }\end{array}$ & 2626 & 94 \\
\hline $\begin{array}{l}\text { Journal of Business } \\
\text { Venturing }\end{array}$ & $\begin{array}{l}\text { McDougall, Shane \& } \\
\text { Oviatt }\end{array}$ & 1994 & $\begin{array}{l}\text { Explaining the formation of international new ventures: The limits of } \\
\text { theories from international business research }\end{array}$ & 1943 & 81 \\
\hline $\begin{array}{l}\text { Academy of } \\
\text { Management Journal }\end{array}$ & Hmieleski \& Baron & 2009 & $\begin{array}{l}\text { Entrepreneur's optimism and new venture performance: A social } \\
\text { cognitive perspective }\end{array}$ & 619 & 69 \\
\hline $\begin{array}{l}\text { Academy of } \\
\text { Management Journal }\end{array}$ & Beckman & 2006 & The influence of founding team company affiliations on firm behaviour & 663 & 55 \\
\hline Journal of Management & $\begin{array}{l}\text { Klotz, Hmieleski, } \\
\text { Bradley \& Busenitz }\end{array}$ & 2014 & $\begin{array}{l}\text { New Venture Teams: A Review of the Literature and Roadmap for Future } \\
\text { Research. }\end{array}$ & 187 & 47 \\
\hline $\begin{array}{l}\text { Journal of Business } \\
\text { Venturing }\end{array}$ & $\begin{array}{l}\text { Ucbasaran, Westhead, } \\
\text { Wright \& Flores }\end{array}$ & 2010 & $\begin{array}{l}\text { The nature of entrepreneurial experience, business failure and } \\
\text { comparative optimism }\end{array}$ & 371 & 46 \\
\hline $\begin{array}{l}\text { Journal of Business } \\
\text { Venturing }\end{array}$ & Clarysse \& Moray & 2004 & $\begin{array}{l}\text { A process study of entrepreneurial team formation: the case of a } \\
\text { research-based spin-off }\end{array}$ & 611 & 44 \\
\hline $\begin{array}{l}\text { Journal of Business } \\
\text { Venturing }\end{array}$ & $\begin{array}{l}\text { Beckman, Burton \& } \\
\text { O'Reilly }\end{array}$ & 2007 & $\begin{array}{l}\text { Early teams: The impact of team demography on VC financing and } \\
\text { going public }\end{array}$ & 457 & 42 \\
\hline $\begin{array}{l}\text { Journal of Small } \\
\text { Business Management }\end{array}$ & Li, Zhao, Tan \& Liu & 2008 & $\begin{array}{l}\text { Moderating Effects of Entrepreneurial Orientation on Market } \\
\text { Orientation-Performance Linkage: Evidence from Chinese Small Firms }\end{array}$ & 398 & 40 \\
\hline Organization Science & Beckman \& Burton & 2008 & $\begin{array}{l}\text { Founding the Future: Path Dependence in the Evolution of Top } \\
\text { Management Teams from Founding to IPO }\end{array}$ & 379 & 38 \\
\hline $\begin{array}{l}\text { Journal of Business } \\
\text { Venturing }\end{array}$ & $\begin{array}{l}\text { Haynie, Shepherd, } \\
\text { Mosakowski \& Earley }\end{array}$ & 2010 & A situated meta cognitive model of the entrepreneurial mindset & 290 & 36 \\
\hline $\begin{array}{l}\text { Entrepreneurship } \\
\text { Theory and Practice }\end{array}$ & $\begin{array}{l}\text { De Carolis, Litzky \& } \\
\text { Eddleston }\end{array}$ & 2009 & $\begin{array}{l}\text { Why Networks Enhance the Progress of New Venture Creation: The } \\
\text { Influence of Social Capital and Cognition }\end{array}$ & 326 & 36 \\
\hline $\begin{array}{l}\text { Journal of Business } \\
\text { Venturing }\end{array}$ & $\begin{array}{l}\text { Amason, Shrader \& } \\
\text { Tompson }\end{array}$ & 2006 & $\begin{array}{l}\text { Newness and novelty: Relating top management team composition to } \\
\text { new venture performance }\end{array}$ & 404 & 34 \\
\hline $\begin{array}{l}\text { Academy of } \\
\text { Management Journal }\end{array}$ & $\begin{array}{l}\text { Sine, Mitsuhashi \& } \\
\text { Kirsch }\end{array}$ & 2006 & $\begin{array}{l}\text { Revisiting Burns and Stalker: Formal Structure and new Venture } \\
\text { Performance in emerging economic Sectors }\end{array}$ & 401 & 33 \\
\hline $\begin{array}{l}\text { Journal of Applied } \\
\text { Psychology }\end{array}$ & Foo, Uy \& Baron & 2009 & $\begin{array}{l}\text { How do feelings influence effort? An empirical study of entrepreneurs } \\
\text { affect and venture effort. }\end{array}$ & 298 & 33 \\
\hline $\begin{array}{l}\text { Entrepreneurship } \\
\text { Theory and Practice }\end{array}$ & $\begin{array}{l}\text { Kickul, Gundry, } \\
\text { Barbosa \& Whitcanack }\end{array}$ & 2009 & $\begin{array}{l}\text { Intuition Versus Analysis? Testing Differential Models of Cognitive Style } \\
\text { on Entrepreneurial Self-Efficacy and the New Venture Creation Process }\end{array}$ & 295 & 33 \\
\hline $\begin{array}{l}\text { Entrepreneurship } \\
\text { Theory and Practice }\end{array}$ & Ensley \& Pearson & 2005 & $\begin{array}{l}\text { An Exploratory Comparison of the Behavioral Dynamics of Top } \\
\text { Management Teams in Family and Nonfamily New Ventures: Cohesion, } \\
\text { Conflict, Potency, and Consensus }\end{array}$ & 369 & 28 \\
\hline $\begin{array}{l}\text { Journal of Small } \\
\text { Business Management }\end{array}$ & $\begin{array}{l}\text { Edelman, Brush, } \\
\text { Manolova \& Greene }\end{array}$ & 2010 & $\begin{array}{l}\text { Start-up Motivations and Growth Intentions of Minority Nascent } \\
\text { Entrepreneurs }\end{array}$ & 227 & 28 \\
\hline $\begin{array}{l}\text { Entrepreneurship } \\
\text { Theory and Practice }\end{array}$ & $\begin{array}{l}\text { Ucbasaran, Lockett, } \\
\text { Wright \& Westhead }\end{array}$ & 2003 & $\begin{array}{l}\text { Entrepreneurial Founder Teams: Factors Associated with Member Entry } \\
\text { and Exit }\end{array}$ & 424 & 28 \\
\hline $\begin{array}{l}\text { Entrepreneurship } \\
\text { Theory and Practice }\end{array}$ & West & 2007 & $\begin{array}{l}\text { Collective Cognition: When Entrepreneurial Teams, Not Individuals, } \\
\text { Make Decisions }\end{array}$ & 303 & 28 \\
\hline Journal of Management & Hmieleski \& Cole & 2012 & Shared Authentic Leadership and New Venture Performance. & 159 & 27 \\
\hline Management Science & $\begin{array}{l}\text { Hoogendoorn, } \\
\text { Oosterbeek \& van Praag }\end{array}$ & 2011 & $\begin{array}{l}\text { The Impact of Gender Diversity On The Performance of Business } \\
\text { Teams: Evidence From A Field Experiment. }\end{array}$ & 181 & 26 \\
\hline $\begin{array}{l}\text { Journal of Business } \\
\text { Venturing }\end{array}$ & Harper & 2008 & Towards a theory of entrepreneurial teams & 252 & 25 \\
\hline $\begin{array}{l}\text { Journal of Business } \\
\text { Venturing }\end{array}$ & Hoang \& Gimeno & 2010 & $\begin{array}{l}\text { Becoming A Founder: How Founder Role Identity Affects } \\
\text { Entrepreneurial Transitions and Persistence In Founding }\end{array}$ & 203 & 25 \\
\hline $\begin{array}{l}\text { Entrepreneurship } \\
\text { Theory and Practice }\end{array}$ & $\begin{array}{l}\text { Discua Cruz, Howorth } \\
\& \text { Hamilton }\end{array}$ & 2013 & $\begin{array}{l}\text { Intrafamily Entrepreneurship: The Formation and Membership of Family } \\
\text { Entrepreneurial Teams. }\end{array}$ & 126 & 25 \\
\hline
\end{tabular}


To provide a detailed overview, the five most cited articles with the highest impact are as follows:

1. Zhao et al. [84] conduct a meta-analysis on the relationship of personality and venture performance and suggest that personality plays a vital role in the emergence and success of entrepreneurs;

2. Cardon et al. [15] conceptualize the nature of entrepreneurial passion associated with salient entrepreneurial role identities;

3. Eisenhardt and Schoonhoven [25] describe the influence of the environment and the founding team on venture success;

4. Stam and Elfring [72] study the relationship between entrepreneurial orientation and performance and find that network centrality and bridging ties moderate this relationship;

5. McDougall et al. [58] provide an explanation of ET formation.

The 30 most cited articles were mainly covered by three journals: $27 \%$ were published in $J B V, 23 \%$ were published in
ET\&P, and $13 \%$ were published in $A M J$.

\subsection{Research Design}

Table 6 shows that a majority of the articles used empirical techniques (67\%). The most common research design used is empirical quantitative, which accounts for approximately $56 \%$ of the total number of studies. The other frequently used technique is conceptual qualitative $(20 \%)$. In the initial days of ET research, as expected, a majority of the studies used conceptual qualitative approaches, and as the field progressed, more empirical studies were performed to validate and test the conceptual findings [34]. In P1, for example, out of the 8 research papers published, four were conceptual and mainly focused on setting a general research agenda for entrepreneurial teams $[48,39]$ and on the question of team formation $[47,58]$. In the subsequent periods, these conceptual studies and calls for empirical validation were answered by a majority of empirical quantitative studies.

Table 6. Research designs and their use in ET research.

\begin{tabular}{|c|c|c|c|c|c|c|c|c|c|c|c|c|c|}
\hline \multirow{2}{*}{ Research Design } & \multicolumn{2}{|l|}{ P1 } & \multicolumn{2}{|l|}{ P2 } & \multicolumn{2}{|l|}{ P3 } & \multicolumn{2}{|l|}{$\mathbf{P 4}$} & \multicolumn{2}{|l|}{ P5 } & \multicolumn{2}{|c|}{ Total } & \multirow{2}{*}{$\begin{array}{l}\text { Average } \\
\text { sample size }\end{array}$} \\
\hline & No. & $\%$ & No. & $\%$ & No. & $\%$ & No. & $\%$ & No. & $\%$ & No. & $\%$ & \\
\hline Quantitative & 2 & 25 & 6 & 75 & 20 & 67 & 39 & 72 & 33 & 73 & 100 & 69 & \\
\hline Empirical & 2 & 25 & 5 & 63 & 15 & 50 & 34 & 63 & 25 & 56 & 81 & 56 & \\
\hline Survey & 1 & 13 & 4 & 50 & 12 & 40 & 28 & 52 & 17 & 38 & 62 & 43 & \\
\hline cross-sectional & 1 & 13 & 4 & 50 & 8 & 27 & 22 & 41 & 11 & 24 & 46 & 32 & 1741 \\
\hline longitudinal & 0 & 0 & 0 & 0 & 4 & 13 & 6 & 11 & 6 & 13 & 16 & 11 & 102 \\
\hline Interviews & 0 & 0 & 1 & 13 & 3 & 10 & 4 & 7 & 3 & 7 & 11 & 8 & \\
\hline longitudinal & 0 & 0 & 0 & 0 & 1 & 3 & 3 & 6 & 3 & 7 & 7 & 5 & 172 \\
\hline Experiment & 1 & 13 & 0 & 0 & 0 & 0 & 2 & 4 & 5 & 11 & 8 & 6 & \\
\hline cross-sectional & 0 & 0 & 0 & 0 & 0 & 0 & 2 & 4 & 4 & 9 & 6 & 4 & 656 \\
\hline longitudinal & 1 & 13 & 0 & 0 & 0 & 0 & 0 & 0 & 1 & 2 & 2 & 1 & 54 \\
\hline Secondary Data & 0 & 0 & 1 & 13 & 3 & 10 & 4 & 7 & 7 & 16 & 15 & 10 & \\
\hline Administrative data & 0 & 0 & 0 & 0 & 1 & 3 & 1 & 2 & 2 & 4 & 4 & 3 & \\
\hline cross-sectional & 0 & 0 & 0 & 0 & 1 & 3 & 1 & 2 & 2 & 4 & 4 & 3 & 567 \\
\hline Other databases & 0 & 0 & 1 & 13 & 2 & 7 & 3 & 6 & 5 & 11 & 11 & 8 & \\
\hline cross-sectional & 0 & 0 & 1 & 13 & 2 & 7 & 3 & 6 & 2 & 4 & 8 & 6 & 167 \\
\hline longitudinal & 0 & 0 & 0 & 0 & 0 & 0 & 0 & 0 & 3 & 7 & 3 & 2 & 1029 \\
\hline Conceptual & 0 & 0 & 0 & 0 & 2 & 7 & 1 & 2 & 1 & 2 & 4 & 3 & \\
\hline Content analysis & 0 & 0 & 0 & 0 & 2 & 7 & 1 & 2 & 1 & 2 & 4 & 3 & \\
\hline Qualitative & 6 & 75 & 2 & 25 & 10 & 33 & 15 & 28 & 12 & 27 & 45 & 31 & \\
\hline Empirical (case study) & 2 & 25 & 0 & 0 & 4 & 13 & 4 & 7 & 6 & 13 & 16 & 11 & \\
\hline Interviews & 2 & 25 & 0 & 0 & 4 & 13 & 4 & 7 & 6 & 13 & 16 & 11 & \\
\hline cross-sectional & 2 & 25 & 0 & 0 & 1 & 3 & 2 & 4 & 2 & 4 & 7 & 5 & 29 \\
\hline longitudinal & 0 & 0 & 0 & 0 & 3 & 10 & 2 & 4 & 4 & 9 & 9 & 6 & 61 \\
\hline Conceptual & 4 & 50 & 2 & 25 & 6 & 20 & 11 & 20 & 6 & 13 & 29 & 20 & \\
\hline Literature review & 2 & 25 & 0 & 0 & 2 & 7 & 5 & 9 & 3 & 7 & 12 & 8 & \\
\hline Theoretical modelling & 2 & 25 & 2 & 25 & 4 & 13 & 6 & 11 & 3 & 7 & 17 & 12 & \\
\hline
\end{tabular}

The two most frequently used methods for data collection in ET research are interviews and surveys. Approximately $61 \%$ of the research in the ET field has been based on data collected from interviews and surveys and strongly favours surveys over interviews. One of the reasons for such a shift is the development of communication technologies that make it easier to collect data. Among the 145 articles, there are four conceptual content analyses [84] and a steady number of literature reviews $[46,82]$.

In addition, an interesting result originates from a comparison of cross-sectional and longitudinal data sets. In the first two periods, only one longitudinal study was conducted; in the last two periods, 28 studies had a longitudinal setup. The lack of longitudinal research has often been criticized as a key weakness of entrepreneurial team research and has clearly been addressed over the last 
decade. Nevertheless, the possible deep-level analysis of our data indicates that longitudinal data are still scarce, particularly in the field of emergent states. Out of the 19 articles that focus on emerging states, only four take a longterm perspective, although researchers have been calling for more such papers. For example, Arthur et al. [3] emphasize that 'continued interaction among team members provides a basis for which the team members can better estimate the presence of an emergent state'. This observation is in line with one of Coultas et al.'s [21] major issues: 'incorporating time into emergent state models'.

For several years, the empirical research on real teams has grown multifold [36, 74]. Overall, $56 \%$ of all studies use real teams as focus groups. However, almost half of the studies either focus on other subject groups (such as students) or no test subjects at all. The primary reason for such behaviour is the difficulty faced by researchers in obtaining access to start-ups. Additionally, start-ups limit the amount of information that they reveal, which proves to be a limitation for any study [71]. In the future, research that focuses on real venture teams will be more fruitful for the study of ET, as any research done on other sample groups may produce distorted results that cannot be applied to real entrepreneurs, thereby restricting the validity of the results [51].

\subsection{Focus on Industry}

Most of the reviewed studies focused on multiple industries, were theoretical or could not be classified. Of the remaining articles, 38\% conducted research in the tech industry, and $3 \%$ conducted research in the service industry. None of the other sectors form a sizable focus of ET research. The reasons for such skewness are probably that technology forms the largest subgroup within the new venture industry and that the availability of data from new start-ups is relatively sparse. Therefore, in addition to using more real entrepreneurs, diversifying the focus to other industries would be beneficial to ET research [71, 72]. It is difficult to generalize the results from a particular sample of the population because the observations of one particular group of people might be very different from another group $[51,23]$. We noticed some progress in this direction, as we see that over the last two periods, the number of theoretical articles as a fraction of total articles has decreased, and the representation from other industries (e.g., manufacturing, banking) has increased.

\section{Discussion and Future Directions}

In this section, we propose reasoned conclusions as to the current thinking in the field and derive suggestions where ET research could position itself in the future based on the trends of the past 10 years. To appreciate the current trends, we (a) draw on the growth of the different sub-streams, (b) the topics recently covered by the top five prolific authors as suggested by Bergh et al. [7], and (c) the content of the most cited papers published in the last decade (by weighted average).

\subsection{Trends in Research Steams}

Team composition research is growing more than any other research stream

In fact, since 2015 the number of published studies about team composition research is both higher than in any fiveyear period in the last 30 years and higher than any other substream. In the last five years, almost $50 \%$ of all ET research published across the 22 journals under consideration was dedicated to team composition research. When analysing diversity research one level deeper, the following underlying trends about surface-level and deep-level diversity can be detected:

\subsubsection{Surface-Level Diversity (SLD)}

SLD is the single strongest research stream with $38 \%$ of all research conducted since 2015 in the respective 22 journals. The absolute number of studies across these journals is comparably high compared to other sub-streams, but it has been levelling off at around 7 articles per year for the last 15 years.

The surface-level diversity domain has developed from more basic factors (age, gender, ethnicity) in the 1990s and 2000 s to more differential aspects, such as cultural diversity $[12,67]$, demographic diversity [17, 18], task diversity [33], and experience diversity [77]. Trends over the last ten years show that attention on demographic studies has been declining while more specific factors as experience diversity, educational background, and knowledge are increasing. We interpret this as maturity in surface-level diversity research with the classic research dimensions (age, gender, ethnicity) decreasing, while new research in more specific sub-domains such as educational background, knowledge and family ties is currently growing. However, overall, the SLD domain seems to be mature and levelling off in research intentions.

Suggestions for Surface-Level Diversity Research

Although many different facets of diversity are currently being discussed and the field has reached a level of maturity, the results are still partly contradictory; future research on SLD needs to focus on how it affects team dynamics, emergent states and various team outcomes other than performance, such as team effectiveness and satisfaction [18].

Other favourable direction for future team research would be to explore (1) multiple diversity factors simultaneously, (2) how diversified the team should be along these dimensions, and (3) what boundary conditions achieve the best performance outcomes. A good example of multiple factor diversity analysis is Hewlett et al. [43], who study inherent traits, such as gender, and acquired traits, such as functional background.

Furthermore, it would be promising to study more indirect effects (as opposed to the direct effects) of SLD or even a combination of direct and indirect effects like Dai et al. [22].

\subsubsection{Deep-Level Diversity (DLD)}

Although deep-level diversity research largely disappeared after 2010, it has had a strong renaissance in very recent years and even more so in the last months. DLD - in 
particular entrepreneurial personality research - seems to be an emergent latent trend: still comparatively little has been published (compared to SLD studies), whereas the few articles that cover entrepreneurial DLD enjoy an extraordinarily high interest both by the academic audience (measured by citation) and as a topic chosen by the leading authors of the field.

When analysing more deeply this recent topic chosen by prolific authors and the trends emerging in DLD, we can identify a particular interest in 'passion' and its role on ET dynamics and outcomes: four very recently published articles $[11,15,24,69]$ and the second-most cited article of the 30year period address entrepreneurial passion [15].

Suggestions for Deep-Level Diversity Research

Future research would benefit from studying more profoundly specific entrepreneurship-relevant personality traits as suggested by Klotz et al. [50] rather than the general big five traits. Passion seems to be a particular trending research area in the last two years, but other prosocial constructs such as empathy are also upcoming and are recommended to be explored more deeply in their nature and their diversity effect on team performance. In order to do so, more original entrepreneurship conceptual work would be beneficial to be developed around genuine entrepreneurial traits. The phenomenological approach about entrepreneurial passion from Cardon et al. [16] is a good example.

In general (similar to SLD research), it would be highly valuable to understand the combinations and calibrations and the conditions in which certain traits have a positive influence or even a predictive power of entrepreneurial team success.

\subsection{Methodological Development}

Hoang and Gimeno [46] called for more empirical work on real ventures to deduce the role of diversity in entrepreneurial processes. This call has been addressed in recent years, as there has been a surge in the number of empirical studies based on real entrepreneurs compared to the more theoretically driven earlier decades. Nevertheless, there is still a need for more studies on real entrepreneurial teams. Vanaelst et al. [78] detailed the difficulties that one faces in obtaining access to such data while revealing the need for longitudinal studies. Although the number of longitudinal studies has increased over the last few years, certain fields are still missing a more profound long-term research perspective (e.g., emerging states). In addition, Klotz et al. [50] concluded that although studies have analysed the impact of team composition at several points in the entrepreneurial process - e.g., at entry [31]), during the initial growth stages [29] and at IPO [6] - there is a lack of research that examines the impact of different traits across all stages of the process. We believe that as a result of this gap, our knowledge about the entrepreneurial development process is limited.

\section{Suggestions for Methodological Development}

Considering the trend in the sub-stream of team composition research, the configuration approach (which combines team mean and variance analysis of team members' traits) seems to be an adequate methodological approach, especially to operationalize team deep-level composition analysis over and above simple team mean scores.

To advance further on the deep-level diversity domain, new methods like A. I. based automated text analysis and sources such as social media might serve well to capture entrepreneurial DLD team data at larger scale and measure personality at a distance through psychometric text analysis. Building on these methods NVTs just have to grant access to their team chats (e.g. Slack or WhatsApp) rather than to fill in long surveys over multiple points in time. Through such rich and easy to access data sources, even longitudinal developments of ventures can be studied more easily, e.g. on the staged approaches of trait impact. Boone et al. [11] provide a great example of stage-related types of entrepreneurial passion.

\subsection{Theory Development}

There has been comparatively little conceptual and theoretical development in our understanding of entrepreneurs' traits and their relationship to venture development (Cardon et al. 2009). West [81] and Keupp and Gassmann [49] mention theory development as a general challenge in entrepreneurial research, and Coultas et al. [21] note the lack of construct and definition clarity in one of the sub-streams (emerging states).

\section{Suggestions for Theory Development}

Future research should aim at theoretical development to present a clear picture of the impact of the entrepreneurial team on venture outcome. Generally, we encourage future research to consider either to develop more original entrepreneurial team theory like Harper [41] or Cardon et al. [16] who build on the particularities of the entrepreneurial context or to explore how current dominant 'broader' theoretical perspectives borrowed from management research (e.g., human capital theory, identity theory, and agency theory) can be meaningfully extended with unique entrepreneurship-specific aspects.

Specifically, with a closer view on the current content trend in the ET research towards 'team composition' and also to some extend 'emergent states' research, the multi-level theory of the upper echelon perspective still seems most suited to service the current research trends, given that they are amenable to the unique context of entrepreneurship. However, to follow up more thoroughly on the trend of studying the deep-level characteristics of individuals and how they affect entrepreneurial team composition, processes, emergent states and, as a result, venture performance (e.g., Klotz et al. 2014; [11], also theoretical frameworks need to be developed to analyse the multi-level phenomena of individuals, teams, and ventures, like Cardon [16] demonstrated for entrepreneurial team passion.

We contend that to develop the ET research field to its full potential, emphasis should be placed on widening the scope of research both empirically and theoretically so that the field grows conceptually. Additionally, this widening should 
encourage entrepreneurial team research to build boundaries that are unique to its own domain; and examining the feedback loops among the core sub-streams in the organizing IMO framework that may emerge over time. We are very supportive of future research endeavours with a longitudinal design that include these feedback loops and that investigate how all constructs in the theoretical model influence one another over time.

\section{Conclusion}

In the last 30 years of entrepreneurial team research, team composition appears as the strongest research interest and has been growing more than any other research stream in the last five years. Within the category of team composition, surfacelevel diversity research is the single strongest research stream - while the classic SLD dimensions (age, gender, ethnicity) are decreasing and more specific dimensions such as educational background, knowledge background and family ties are growing. Suggestions for developing this field include (1) focus on how SLD affects team dynamics, emergent states and various proximal team outcomes, (2) analysis of multiple diversity factors simultaneously, and (3) ideal boundary conditions for the best effect of SLD. Despite the low quantity of research output, entrepreneurial deeplevel diversity seems to be an emergent latent trend that receives extraordinarily high interest both by the academic audience (measured by citation) as well as a topic chosen by the leading authors of the field, in particular passion and empathy of entrepreneurial teams. Further research would benefit from more profound analysis of entrepreneurshiprelevant personality research, in particular their composition and configuration effect on emergent states and team outcomes.

Considering the trend in the sub-stream of team composition research, the methodological approaches need to advance further in three ways: (1) application of more sophisticated team analysis like the configuration approach and (2) use of more primary data of the entire team (3) through easy access methods like A. I. based automated text analysis of team chat data (Slack or WhatsApp) as opposed to long psychological questionnaires. This way researchers might capture entrepreneurial DLD team data at large scale and measure personality at a distance through psychometric text analysis.

\section{References}

[1] Albornoz, C. A. (2008). Towards a set of trainable content on entrepreneurship education: a review of entrepreneurship literature from an educational perspective. Journal of Technology Management and Innovation, 3, pp. 86-98.

[2] Amit, R., Glosten, L. and Muller, E. (1990). Entrepreneurial ability, venture investments, and risk sharing. Management Science, 36, pp. 1233-1246.

[3] Arthur, W., Bell, S. T. and Edwards, B. D. (2007). A
Longitudinal examination of the comparative criterion-related validity of additive and referent-shift consensus operationalizations of team efficacy. Organizational Research Methods, 10, pp. 35-58.

[4] Beckman, C. M. (2006). The influence of founding team company affiliations on firm behavior. Academy of Management Journal, 49, pp. 741-758.

[5] Beckman, C. M. and Burton, M. D. (2008). Founding the future: path dependence in the evolution of top management teams from founding to IPO. Organization Science, 19, pp. 324.

[6] Beckman, C. M., Burton, M. D. and O'reilly, C. (2007). Early teams: the impact of team demography on VC financing and going public. Journal of Business Venturing, 22, pp. 147-173.

[7] Bergh, D. D., Perry, J. and Hanke, R. (2006). Some predictors ofSMJ article impact. Strategic Management Journal, 27, pp. 81-100.

[8] Berry, L. L. and Parasuraman, A. (1993). Building a new academic field - the case of services marketing. Journal of Retailing, 69, pp. 13-60.

[9] Bird, B. J. (1989). Entrepreneurial Behaviour. Glenview, IL: Scott, Foresman and Company.

[10] Birley, S. (1985). The role of networks in the entrepreneurial process. Journal of Business Venturing, 1, pp. 107-117.

[11] Boone, S., Andries, P. and Clarysse, B. (2019). Does team entrepreneurial passion matter for relationship conflict and team performance? On the importance of fit between passion focus and venture development stage. Journal of Business Venturing, pp. 105984. doi: 10.1016/j.jbusvent.2019.105984.

[12] Bouncken, R. B. (2004). Cultural diversity in entrepreneurial teams: findings of new ventures in Germany. Creativity and Innovation Management, 13, pp. 240-253.

[13] Busenitz, L., Moesel, D. D., Fiet, J. O. and Barney, J. B. (2003). Entrepreneurship research in emergence: past trends and future directions. Journal of Management, 29, pp. 285308 .

[14] Busenitz, L. W., Fiet, J. O. and Moesel, D. D. (2005). Signaling in venture capitalist-new venture team funding decisions: does it indicate long-term venture outcomes? Entrepreneurship Theory and Practice, 29, pp. 1-12.

[15] Cardon, M. S., Wincent, J., Singh, J. and Drnovsek, M. (2009). The nature and experience of entrepreneurial passion. Academy of Management Review, 34, pp. 511-532.

[16] Cardon, M. S., Glauser, M., Murnieks, C. Y. (2017). Passion for what? Expanding the domains of entrepreneurial passion. Journal of Business Venturing, 8, pp. 24-32.

[17] Chaganti, R. S., Watts, A. D., Chaganti, R. and ZimmermanTreichel, M. (2008). Ethnic-immigrants in founding teams: effects on prospector strategy and performance in new Internet ventures. Journal of Business Venturing, 23, pp. 113-139.

[18] Chowdhury, S. (2005). Demographic diversity for building an effective entrepreneurial team: is it important? Journal of Business Venturing, 20, pp. 727-746.

[19] Clarysse, B. and Moray, N. (2004). A process study of entrepreneurial team formation: the case of a research-based spin-off. Journal of Business Venturing, 19, pp. 55-79. 
[20] Cooper, A. C. and Bruno, A. V. (1977). Success among hightechnology firms. Business Horizons, 20, pp. 16-22.

[21] Coultas, C. W., Driskell, T., Burke, C. S. and Salas, E. (2014). A conceptual review of emergent state measurement. Small Group Research, 45, pp. 671-703.

[22] Dai, Y., Gukdo, B. and Fangsheng, D. (2019). The direct and indirect impact of gender diversity in new venture teams on innovation performance. Entrepreneurship Theory and Practice, 43, pp. 419-436.

[23] De Carolis, D. M., Litzky, B. E. and Eddleston, K. A. (2009). Why networks enhance the progress of new venture creation: the influence of social capital and cognition. Entrepreneurship Theory and Practice, 33, pp. 527-545.

[24] De Mol, E., Cardon, M. S., De Jong, B., Khapova, S. N. and Elfring, T. (2019). Entrepreneurial passion diversity in new venture teams: an empirical examination of short- and longterm performance implications. Journal of Business Venturing, pp. 105965. doi: 10.1016/j.jbusvent.2019.105965.

[25] Eisenhardt, K. M. and Schoonhoven, C. B. (1990). Organizational growth: linking founding team, strategy, environment, and growth among U.S. semiconductor ventures, 1978-1988. Administrative Science Quarterly, 35, pp. 504-529.

[26] Elo, S. and Kyngäs, H. (2007). The qualitative content analysis process. Journal of Advanced Nursing, 62, pp. 107-115.

[27] Ensley, M. D., Hmieleski, K. M. and Pearce, C. L. (2006). The importance of vertical and shared leadership within new venture top management teams: implications for the performance of startups. The Leadership Quarterly, 17, pp. 217-231.

[28] Ensley, M. D., Pearson, A. and Pearce, C. L. (2003). Top management team process, shared leadership, and new venture performance: a theoretical model and research agenda. Human Resource Management Review, 13, pp. 329-346.

[29] Ensley, M. D. and Pearson, A. W. (2005). An exploratory comparison of the behavioral dynamics of top management teams in family and nonfamily new ventures: cohesion, conflict, potency, and consensus. Entrepreneurship Theory and Practice, 29, pp. 267-284.

[30] Foo, M.-D. (2011). Teams developing business ideas: how member characteristics and conflict affect member-rated team effectiveness. Small Business Economics, 36, pp. 33-46.

[31] Foo, M.-D., Sin, H.-P. and Yiong, L.-P. (2006). Effects of team inputs and intrateam processes on perceptions of team viability and member satisfaction in nascent ventures. Strategic Management Journal, 27, pp. 389-399.

[32] Foo, M.-D., Uy, M. A. and Baron, R. A. (2009). How do feelings influence effort? An empirical study of entrepreneurs' affect and venture effort. Journal of Applied Psychology, 94, pp. 1086-1094.

[33] Foo, M. D., Kam Wong, P. and Ong, A. (2005). Do others think you have a viable business idea? Team diversity and judges' evaluation of ideas in a business plan competition. Journal of Business Venturing, 20, pp. 385-402.

[34] Forbes, D. P., Borchert, P. S., Zellmer-Bruhn, M. E. and Sapienza, H. J. (2006). Entrepreneurial team formation: an exploration of new member addition. Entrepreneurship Theory and Practice, 30, pp. 225-248.
[35] Francis, D. H. and Sandberg, W. R. (2000). Friendship within entrepreneurial teams and its association with team and venture performance. Entrepreneurship Theory and Practice, 25 , pp. 5-26.

[36] Franke, N., Gruber, M., Harhoff, D. and Henkel, J. (2006). What you are is what you like-similarity biases in venture capitalists' evaluations of start-up teams. Journal of Business Venturing, 21, pp. 802-826.

[37] Franke, N. and Schreier, M. (2008). A meta-ranking of technology and innovation management/ entrepreneurship journals. Die Betriebswirtschaft, 68, pp. 185-216.

[38] Furrer, O., Thomas, H. and Goussevskaia, A. (2008). The structure and evolution of the strategic management field: a content analysis of 26 years of strategic management research. International Journal of Management Reviews, 10, pp. 1-23.

[39] Gartner, W. B., Shaver, K. G., Gatewood, E. and Katz, J. A. (1994). Finding the entrepreneur in entrepreneurship. Entrepreneurship Theory and Practice, 18, pp. 5-9.

[40] Ginsberg, A. and Venkatraman, N. (1985). Contingency perspectives of organizational strategy: a critical review of the empirical research. Academy of Management Review, 10, pp. 421-434.

[41] Harper, D. A. (2008). Towards a theory of entrepreneurial teams. Journal of Business Venturing, 23 (6), pp. 613-626.

[42] Harrison, D. A., Price, K. H. and Bell, M. P. (1998). Beyond relational demography: time and the effects of surface- and deep-level diversity on work group cohesion. Academy of Management Journal, 41, pp. 96-107.

[43] Hewlett, S. A., Marshall, M., Sherbin, L. (2013). How diversity can drive innovation. Harvard Business Review.

[44] Hmieleski, K. M. and Baron, R. A. (2009). Entrepreneurs' optimism and new venture performance: a social cognitive perspective. Academy of Management Journal, 52, pp. 473-488.

[45] Hmieleski, K. M. and Ensley, M. D. (2007). A contextual examination of new venture performance: entrepreneur leadership behavior, top management team heterogeneity, and environmental dynamism. Journal of Organizational Behavior, 28, pp. 865-889.

[46] Hoang, H. and Gimeno, J. (2010). Becoming a founder: how founder role identity affects entrepreneurial transitions and persistence in founding. Journal of Business Venturing, 25, pp. $41-53$.

[47] Kamm, J. B. and Nurick, A. J. (1993). The stages of team venture formation: a decision-making model. Entrepreneurship Theory and Practice, 17, pp. 17-27.

[48] Kamm, J. B., Shuman, J. C., Seeger, J. A. and Nurick, A. J. (1990). Entrepreneurial teams in new venture creation: a research agenda. Entrepreneurship Theory and Practice, 14, pp. 7-17.

[49] Keupp, M. M. and Gassmann, O. (2009). The past and the future of international entrepreneurship: a review and suggestions for developing the field. Journal of Management, 35 , pp. 600-633.

[50] Klotz, A. C., Hmieleski, K. M., Bradley, B. H. and Busenitz, L. W. (2014). New venture teams. Journal of Management, 40, pp. 226-255. 
[51] Lester, S. W., Meglino, B. M. and Korsgaard, M. A. (2002). The antecedents and consequences of group potency: a longitudinal investigation of newly formed work groups. Academy of Management Journal, 45, pp. 352-368.

[52] Li, Y., Zhao, Y., Tan, J. and Liu, Y. (2008). Moderating effects of entrepreneurial orientation on market orientationperformance linkage: evidence from chinese small firms. Journal of Small Business Management, 46, pp. 113-133.

[53] Lim, J. Y.-K., Busenitz, L. W. and Chidambaram, L. (2013). New venture teams and the quality of business opportunities identified: faultlines between subgroups of founders and investors. Entrepreneurship Theory and Practice, 37, pp. 4767.

[54] Marks, M. A., Mathieu, J. E. and Zaccaro, S. J. (2001). A temporally based framework and taxonomy of team processes. Academy of Management Review, 26, pp. 356-376.

[55] Maschke, K. and Zu Knyphausen-Aufse $\beta$, D. (2012). How the entrepreneurial top management team setup influences firm performance and the ability to raise capital: a literature review. Business Research, 5, pp. 83-123.

[56] Mathieu, J., Maynard, M. T., Rapp, T. and Gilson, L. (2008). Team effectiveness 1997-2007: a review of recent advancements and a glimpse into the future. Journal of Management, 34, pp. 410-476.

[57] McClelland, D. (1961). The Achieving Society. Princeton, NJ: Van Nostrand.

[58] McDougall, P. P., Shane, S. and Oviatt, B. M. (1994). Explaining the formation of international new ventures: the limits of theories from international business research. Journal of Business Venturing, 9, pp. 469-487.

[59] McGrath, J. E. (1964). Social Psychology: A Brief Introduction. New York, NY: Holt, Rinehart and Winston.

[60] Milliken, F. J. and Martins, L. L. (1996). Searching for common threads: understanding the multiple effects of diversity in organizational groups. Academy of Management Review, 21, pp. 402-433.

[61] Mosakowski, E. (1998). Entrepreneurial resources, organizational choices, and competitive outcomes. Organization Science, 9, pp. 625-643.

[62] Murphy, P. J. (2011). A $2 \times 2$ nceptual foundation for entrepreneurial discovery theory. Entrepreneurship Theory and Practice, 35, pp. 359-374.

[63] Newman, A., Obschonka, M., Moeller, J. and Chandan, G. G. (2019). Entrepreneurial passion: a review, synthesis, and agenda for future research. Applied Psychology. doi: 10.1111/apps. 12236

[64] Omri, A. and Boujelbene, Y. (2018). Success factors of entrepreneurial teams: modeling through the cognitive mapping. Journal of Entrepreneurship and Management, 7, pp. 1-9.

[65] Podsakoff, P. M., Mackenzie, S. B., Bachrach, D. G. and Podsakoff, N. P. (2005). The influence of management journals in the 1980s and 1990s. Strategic Management Journal, 26, pp. 473-488.

[66] Rauch, A. and Frese, M. (2007). Let's put the person back into entrepreneurship research: a meta-analysis on the relationship between business owners' personality traits, business creation, and success. European Journal of Work and Organizational Psychology, 16, pp. 353-385.

[67] Richard, O. C., Barnett, T., Dwyer, S. and Chadwick, K. (2004). Cultural diversity in management, firm performance, and the moderating role of entrepreneurial orientation dimensions. Academy of Management Journal, 47, pp. 255266.

[68] Ruef, M., Aldrich, H. E. and Carter, N. M. (2003). The structure of founding teams: homophily, strong ties, and isolation among U.S. entrepreneurs. American Sociological Review, 68, pp. 195-225.

[69] Santos, S. C. and Cardon, M. S. (2019). What's love got to do with it? Team entrepreneurial passion and performance in new venture teams. Entrepreneurship Theory and Practice, 43, pp. 475-504.

[70] Shepherd, D. A. and Krueger, N. F. (2002). An intentionsbased model of entrepreneurial teams' social cognition. Entrepreneurship Theory and Practice, 27, pp. 167-185.

[71] Sine, W. D., Mitsuhashi, H. and Kirsch, D. A. (2006). Revisiting burns and stalker: formal structure and new venture performance in emerging economic sectors. Academy of Management Journal, 49, pp. 121-132.

[72] Stam, W. and Elfring, T. (2008). Entrepreneurial orientation and new venture performance: the moderating role of intraand extraindustry social capital. Academy of Management Journal, 51, pp. 97-111.

[73] Tahai, A. and Meyer, M. J. (1999). A revealed preference study of management journals' direct influences. Strategic Management Journal, 20, pp. 279-296.

[74] Talaulicar, T., Grundei, J. and Werder, A. V. (2005). Strategic decision making in start-ups: the effect of top management team organization and processes on speed and comprehensiveness. Journal of Business Venturing, 20, pp. 519-541.

[75] Timmons, J. A. (1979). Careful self-analysis and team assessment can aid entrepreneurs. Harvard Business Review, 57, pp. 198-206.

[76] Tranfield, D., Denyer, D. and Smart, P. (2003). Towards a methodology for developing evidence-informed management knowledge by means of systematic review. British Journal of Management, 14, pp. 207-222.

[77] Ucbasaran, D., Lockett, A., Wright, M. and Westhead, P. (2003). Entrepreneurial founder teams: factors associated with member entry and exit. Entrepreneurship Theory and Practice, 28, pp. 107-128.

[78] Vanaelst, I., Clarysse, B., Wright, M., Lockett, A., Moray, N. and S'jegers, R. (2006). Entrepreneurial team development in academic spinouts: an examination of team heterogeneity. Entrepreneurship Theory and Practice, 30, pp. 249-271.

[79] Walske, J. M. and Zacharakis, A. (2009). Genetically engineered: why some venture capital firms are more successful than others. Entrepreneurship Theory and Practice, 33, pp. 297-318.

[80] Weick, K. E. (1995). What theory is not, theorizing is. Administrative Science Quarterly, 40, pp. 385-390. 
[81] West, G. P. (2007). Collective cognition: when entrepreneurial teams, not individuals, make decisions. Entrepreneurship Theory and Practice, 31, pp. 77-102.

[82] Wright, M., Hmieleski, K. M., Siegel, D. S. and Ensley, M. D. (2007). The role of human capital in technological entrepreneurship. Entrepreneurship Theory and Practice, 31, pp. 791-806.

[83] Zacharakis, A. L. and Meyer, G. D. (1998). A lack of insight: do venture capitalists really understand their own decision process? Journal of Business Venturing, 13, pp. 57-76.
[84] Zhao, H., Seibert, S. E. and Lumpkin, G. T. (2010). The relationship of personality to entrepreneurial intentions and performance: a meta-analytic review. Journal of Management, 36, pp. 381-404.

[85] Zhou, W. (2016). When does shared leadership matter in entrepreneurial teams: the role of personality composition. International Entrepreneurship and Management Journal, 12, pp. 153-169. 